\title{
SYMPOSIUM ON THE IMPACT OF INDIGENOUS PEOPLES ON INTERNATIONAL LAW
}

\section{INDIGENOUS PEOPLES AND DIPLOMACY ON THE WORLD STAGE}

\author{
Kristen Carpenter ${ }^{*}$ and Alexey Tsykarev ${ }^{*}$
}

Indigenous Peoples are emerging as diplomats on the world stage. With states relinquishing some "soft power" space to non-state actors, the role of Indigenous Peoples in international diplomacy ${ }^{1}$ and particularly human rights diplomacy is both distinctive and important. ${ }^{2}$

Indigenous Peoples are neither states nor international organizations nor NGOs; they are peoples with distinct polities, languages, cultures, and worldviews from those around them. ${ }^{3}$ For over a century, they have participated in international processes, first at the margins and now with the increasing attention and recognition of state parties. ${ }^{4}$ This trend, embodied by the UN General Assembly's adoption of the Declaration on the Rights of Indigenous Peoples in $2007,{ }^{5}$ reflects the applicability of human rights to peoples (not just individuals) and the interconnectedness of a variety of world actors (not just states). A watershed instrument in human rights, the Declaration recognizes Indigenous Peoples' rights to self-determination and equality, along with land, culture, religion, and many other dimensions of their individual and collective existence.

As their focus turns to the Declaration's implementation, Indigenous Peoples are asserting various modes of engagement based on their values, timeframes, and visions for their own well-being and for the world more broadly. Taking account of these developments, this essay identifies several examples of Indigenous Peoples as diplomats based on their traditions of diplomacy. ${ }^{6}$

\section{Frameworks and Developments}

Indigenous Peoples have always had traditions of diplomacy to regulate their external relationships with others. For example, the Haudenosaunee Great Law of Peace and Confederacy have promoted cooperation among

\footnotetext{
* Council Tree Professor of Law and Director of the American Indian Law Program, University of Colorado Law School, Boulder, Colorado, United States; member of the UN Expert Mechanism on the Rights of Indigenous Peoples.

* Chair of the Center for Support of Indigenous Peoples and Civic Diplomacy, Karelia, Russia; member of the UN Permanent Forum on Indigenous Issues; previously served on the UN Expert Mechanism on the Rights of Indigenous Peoples.

${ }^{1}$ See J. Marshall Bier, Indigenous Diplomacies 2 (2009) (considering the "character and effect" of Indigenous diplomacies).

2 See Kelly Kate Pease, Human Rights and Humanitarian Diplomacy 1 (2016). For a discussion of Indigenous Peoples in international trade, see, e.g., Sergio Puig, International Indigenous Economic Law, 52 U.C. DAvis L. Rev. 1243 (2019).

3 See S. James Anaya, Indigenous Peoples in International Law (2d ed. 2004).

${ }^{4}$ See Kristen A. Carpenter and Angela R. Riley, Indigenous Peoples and the Jurisgenerative Moment in Human Rights, 102 CAL. L. REv. 163 (2014).

${ }^{5}$ UN Declaration on the Rights of Indigenous Peoples, G.A. Res. 61/295, para. 12 (Sept. 13, 2007).

${ }^{6}$ For example, Andrew Cooper et Al., The Oxford Handbook of Modern Diplomacy (2013), is a wonderful resource, but contains only scant and outdated references to "Indigenous populations" among its 952 pages.
}

(C) Kristen Carpenter and Alexey Tsykarev 2021. This is an Open Access article, distributed under the terms of the Creative 118 Commons Attribution licence (http://creativecommons.org/licenses/by/4.0/), which permits unrestricted re-use, distribution, and reproduction in any medium, provided the original work is properly cited. 
Indigenous nations, including the Mohawk, Cayuga, Onondaga, Oneida, and Seneca, since before contact with Europeans. ${ }^{7}$ Indeed in the 1500s-1900s, Indigenous Peoples throughout the Americas brought their own political and cultural traditions to bear on treaty-based diplomacy with Europeans, even as the latter used increasing violence against them. These traditions included rituals for establishing relationships and expressions of sacred obligations. In modern times, Indigenous Peoples, such as the Maori and Haudenosaunee, sent representatives to the League of Nations and United Nations. Contemporarily, Indigenous Peoples have been involved in a panoply of international processes, perhaps mostly notably, drafting and advancing the Declaration. ${ }^{8}$ Through shared cultural norms and practices, they worked through many differences to advance common points, such as the collective nature of their rights and spiritual attachment to lands, now recognized in the Declaration. ${ }^{9}$

Since the General Assembly's adoption of the Declaration in 2007, Indigenous Peoples have turned their attention to its implementation. ${ }^{10}$ This task triggers new questions of diplomacy, namely how to move from formalization to realization of human rights. Throughout the world, Indigenous Peoples are seeking to persuade states to embrace the Declaration. Here we identify a number of developments at the United Nations, while recognizing that recent events within regional bodies, ${ }^{11}$ states, ${ }^{12}$ and Indigenous Peoples ${ }^{13}$ could also reveal fruitful areas for research into Indigenous Peoples' diplomacy.

\section{Indigenous Peoples' Mechanisms: Spotlight on the Permanent Forum and Expert Mechanism}

The United Nations now has five bodies devoted to Indigenous Peoples: the UN Permanent Forum on Indigenous Issues, the Special Rapporteur on the Rights of Indigenous Peoples, the Expert Mechanism on the Rights of Indigenous Peoples (EMRIP), the Voluntary Fund for Indigenous Populations, ${ }^{14}$ and the newly created Local Communities and Indigenous Peoples Platform within the UN Climate Change infrastructure. ${ }^{15}$ Each body has its own mandate and modalities for engagement. Here we offer some comments about diplomacy in the Permanent Forum and Expert Mechanism.

The Permanent Forum, comprised of eight state-nominated and eight Indigenous-nominated experts, has become an arena for dialogue and alliance-making toward reaching consensus in decision-making. The Permanent Forum primarily provides space for "rhetorical" diplomacy, where states and Indigenous Peoples can exchange their views. Sometimes "heavier" diplomatic tools are in use, such as the negotiation of agreements, the application of public pressure through the media, and the creation of new diplomatic posts as noted above. The

\footnotetext{
7 See Robert A. Williams, Jr., Linking Arms Together: American Indian Treaty Visions of Law \& Peace, 1600-1800 (1997).

8 See Making the Declaration Work: The United Nations Declaration on the Rights of Indigenous Peoples (Claire Charters \& Rudolfo Stavenhagen eds., 2009); Reflections on the UN Declaration on the Rights of Indigenous Peoples (Stephen Allen \& Alexandra Xanthaki eds., 2011).

9 See Sakej Henderson, Indigenous Diplomacies and the UN Declaration on the Rights of Indigenous Peoples (2008).

${ }^{10}$ Implementing the United Nations Declaration on the Rights of Indigenous Peoples in the United States, 91 U. Colo. L. Rev. F. 47 (2020).

${ }^{11}$ Examples range from large state-centric regional bodies like the Organization of American States and African Commission on Human and Peoples' Rights, to smaller Indigenous-focused entities like the Asian Pacific Peoples Pact and Barents Indigenous Peoples Congress.

12 In 2018, Canada created a new position, Special Advisor for Indigenous Issues, based at the Permanent Mission of Canada to the United Nations, and in the United States, a resolution of the National Congress of American Indians has recently called for the Biden administration to appoint an international ambassador on Indigenous affairs.

13 See Galit A. Sarfaty, International Norm Diffusion in the Pimicikamak Cree Nation: A Model of Legal Mediation, 48 HARv. INT'L L. J. 441 (2007) (describing one Indigenous Peoples' internal navigation of human rights norms).

14 See Int’l Work Grp. for Indigenous Affs., The Indigenous World 2019, 582-88, 613-71 (David N. Berger ed., 2019).

${ }^{15}$ Local Communities and Indigenous Peoples Platform, UN Framework Convention on Chimate Change.
} 
Permanent Forum recognizes Indigenous Peoples as "peoples," and distinguishes hierarchies within Indigenous representation: from caucuses to Indigenous parliamentarians to Indigenous governments, providing each with different levels of speaking privileges. It has also become a practice by some so-called "friendly" member states to include Indigenous representatives in official delegations to the Forum sessions, which gives them the privilege to use the floor as state representatives.

The Forum's consensus-building practice is time-intensive and its recommendations are often long range in nature. These features sometimes fuel the perception that the Forum is more of a venue for "steam release" and ritualized discourse than meaningful action. However, as the ultimate adoption of the Declaration after a decades-long process showcases, Indigenous diplomacy often allows for, and even requires, some time for tangible and long-term solutions to emerge. Given the commitment of Indigenous Peoples to intergenerational kinship, sometimes described in terms of "seven generations," such an approach is consistent with many Indigenous worldviews. Taking a long view is also necessary to overcome the decades and centuries of oppression by states and exclusion by international bodies. As one example, after years of advocacy by the Forum, the General Assembly finally proclaimed the International Decade of Indigenous Languages 2022-2032, a system-wide commitment to realizing the cultural, political, economic, and educational rights associated with Indigenous languages. ${ }^{16}$

The Expert Mechanism, a subsidiary body of the Human Rights Council, was created in 2006 to advise the Council regarding Indigenous Peoples' human rights, both through an annual session and thematic reports. ${ }^{17}$ Since 2016, the Expert Mechanism has been further mandated to assist states and Indigenous Peoples in realizing the aims of the Declaration through country engagement (as described below). ${ }^{18}$ One major opportunity for Indigenous Peoples' diplomacy occurs at the annual session in Geneva each summer. After the session begins with a prayer in an Indigenous language, Indigenous Peoples are recognized on their own behalf and make statements regarding thematic studies, country engagements, and other work undertaken by the Expert Mechanism. Although interventions are limited, as they often are at the United Nations, to two or three minutes, many Indigenous speakers invoke their own traditions of rhetoric by making their statements surrounded by community members or addressing the session in their own Indigenous languages (some provide a translation in one of the official UN languages to interpreters). When states respond to these interventions, the resulting dialogue is an intercultural one, thus recognizing the unique relationship between Indigenous Peoples and their lands and languages as aspects of human rights. ${ }^{19}$ These sessions then influence EMRIP recommendations and Council resolutions on Indigenous Peoples' matters. ${ }^{20}$ Over time, this diplomacy expands participation in the interpretation of international obligations of states to realize Indigenous Peoples' human rights.

The Expert Mechanism's new mandate sets forth three modalities for realizing the aims of the Declarationnamely facilitating dialogue, providing technical advice, and coordinating among UN agencies, in response to requests by states and Indigenous Peoples. These modalities are particularly receptive to diplomacy among Indigenous Peoples, states, and others. For example, in 2019, the Expert Mechanism accepted a joint request from Maori and state parties in New Zealand asking for technical advice in developing a national action plan

\footnotetext{
16 See Kristen Carpenter \& Alexey Tsykarev, (Indigenous) Language as a Human Right, 24 UCLA J. INT'L L. \& Foreign AfF. 49 (2020).

${ }^{17}$ Human Rights Council Res. 6/36, UN Doc. A/HRC/RES/6/36 (Dec. 14, 2007).

18 Human Rights Council Res. 33/25, UN Doc. A/HRC/RES/33/25 (Oct. 5, 2016).

${ }^{19}$ For one of many examples of Indigenous Peoples and states interacting at sessions of the UN Expert Mechanism on the Rights of Indigenous Peoples, see, e.g., Opening and Organization of Work - 1st Meeting, 12th Session Expert Mechanism on Rights of Indigenous Peoples (2019).

${ }^{20}$ Human Rights Council Res. 42/L.24, UN Doc. A/HRC/42/L.24 (Sept. 25, 2019).
} 
for implementing the Declaration. ${ }^{21}$ The Expert Mechanism, working together with these joint requesters, was able to plan visits to Maori communities and bring them into dialogue with state parties. The resulting technical advisory note calls for a national action plan that reflects both the obligation of the state to meet its human rights obligations under the Declaration and to do so with the full participation and consultation of Indigenous Peoples, consistent with the safeguard of free, prior, and informed consent. ${ }^{22}$ Following this engagement with the Expert Mechanism, New Zealand has announced its intention to be the first country with a national action plan to implement the Declaration. ${ }^{23}$

In another country engagement, the Yaqui people of Sonora, Mexico, and Arizona, United States, requested the Expert Mechanism's assistance to repatriate a ceremonial object from Sweden. ${ }^{24}$ The sacred Maaso Kova, a deer head consecrated in a religious ritual, was acquired by Danish anthropologists in the 1930s — at a time when the Yaqui people had been driven far from their home to a military camp—and ultimately transferred to the Swedish National Museum of World Culture. For the Yaqui people, the Maaso Kova was a sacred living being that must be returned home, pursuant to Articles 11 and 12 of the Declaration. There were many impediments to resolving the matter of the Maaso Kova. For instance, only states are parties to the 1970 UNESCO Convention prohibiting illicit trafficking of cultural property, and Sweden had not received a formal request from Mexico or the United States, pursuant to the terms of that Convention. ${ }^{25}$

The Yaquis kept raising the issue at the United Nations, with the vocal support of the Sami Parliament of Sweden, which more than once used its own time at UN sessions to advocate for the Yaqui repatriation. Sweden finally agreed to address the matter through the Expert Mechanism's country engagement modality in 2018. Mexico and the United States expressed informal support allowing the process to unfold between the Yaqui people and Sweden directly. The Expert Mechanism laid the groundwork by providing technical advice, for example explicating the substance and legitimacy of both Yaqui law (prohibiting alienation of the Maaso Kova as a living being) and Swedish law (regulating museums' deaccessioning decisions). The participants were open to diplomatic innovations. At one stage, Sweden expressed concern about the potential for competing claims among Yaquis in Mexico and the United States. While the Yaquis already had their own internal norms and processes for dealing with these issues, they gathered to discuss the external concerns. They decided to create a transnational cultural entity, known as the "Maaso Kova Committee," comprised of secular and spiritual leadership from Sonora and Arizona, and authorized to represent the Yaquis in negotiations with Sweden.

Following a number of breakthroughs, the parties met for a dialogue facilitated by the Expert Mechanism in 2020. Voicing a shared desire to take a "human rights approach to repatriation," the Swedish Museum and the Yaqui people reached an agreement in principle to repatriate the Maaso Kova, citing both the UNESCO Convention and the Declaration, and also expressing a willingness to collaborate on programming going forward. Ultimately, there will need to be cooperation with the state of Mexico to transfer the Maaso Kova. The Yaqui and Swedish participants are both anticipating this event as a step toward healing and a good relationship moving forward.

${ }^{21}$ Expert Mechanism on the Rights of Indigenous Peoples, Technical Advisory Note-Country Engagement Mission (8 - 13 April 2019)—New Zealand (July 14, 2019).

${ }^{22}$ Id. See also Study of the Expert Mechanism on the Rights of Indigenous Peoples, Free, Prior, and Informed Consent: A Human Rights Approach, UN Doc. A/HRC/39/62 (Aug. 10, 2018).

23 See Michael Neilson, New Zealand Aims to be First with UN Declaration on Rights of Indigenous Peoples Plan, NZ HerALD (Apr. 17, 2019).

${ }^{24}$ Expert Mechanism on the Rights of Indigenous Peoples, Technical Advisory Note-Repatriation Request for the Yaqui Maaso Kova (June 16, 2020).

${ }^{25}$ Convention on the Means of Preventing and Prohibiting the Illicit Import, Export, and Transfer of Ownership of Cultural Property, Nov. 14, 1970, 823 UNTS 231. 
Issues for Future Study

Developments in the Permanent Forum and Expert Mechanism reflect an optimistic view of Indigenous Peoples' diplomacy. Yet there are challenges to consider as well.

First, there is the problem of uncooperative states. It is one thing to invite Finland, Sweden, New Zealand, and Mexico to engage in diplomacy with Indigenous Peoples. These states are long time leaders in human rights, known as "friends" to Indigenous Peoples. Yet other states are only beginning to overcome an historic reluctance to recognize Indigenous Peoples. ${ }^{26}$ Furthermore, the rise of far-right leaders in some regions threatens human rights diplomacy altogether. States may publicly articulate receptivity to UN visits but, in reality, fail to respond to invitations or delay them indefinitely. Given that the current mechanisms for advancing Indigenous Peoples' rights often rely on state cooperation and political will, versus coercion and enforcement, state inaction leads to stalemate situations.

Second, there are issues of security and economics in which Indigenous Peoples' concerns may be exploited or ignored by superpowers. Today, for example, the United States, China, and Russia are reportedly "scrambling" for economic, military, and transportation footholds in the Arctic. ${ }^{27}$ Yet many Indigenous Peoples have made their home in the Arctic for thousands of years and already have their own transnational governance organizations such as the Inuit Circumpolar Council. Assessing states' attention to Indigenous Peoples' issues necessitates a broader look at their national interests in the region..$^{28}$

Finally, there is the question of diplomatic relations among Indigenous Peoples. The ongoing dominance of states may foster solidarity but also create tension among Indigenous Peoples. There are, for example, many calls to address Indigenous Peoples' participation through their own representative institutions at the United Nations, but there are also different views among Indigenous Peoples about which groups should be able to participate. ${ }^{29}$

Despite these challenges, Indigenous Peoples are asserting their role as diplomats in international processes. With examples including climate change and biodiversity, Indigenous Peoples are showing their capacity to bring a more capacious approach to human rights and the potential for enhancing global well-being. ${ }^{30}$ The Covid-19 pandemic has in some ways diminished opportunities for Indigenous Peoples' international diplomacy, yet it has also provided certain transformations in online access. Drawing from the best of these practices, we anticipate ever-advancing examples of Indigenous Peoples' international diplomacy going forward.

${ }^{26}$ Baher Kamal, Asia: 260 Million Indigenous Peoples Marginalised, Discriminated, InterPress Serv. News Agency (May 26, 2017).

${ }^{27}$ Simon Tisdale, Trump's Bid to Buy Greenland Shows that the 'Scramble for the Arctic' is Truly Upon Us, Guardian (Aug. 24, 2019).

28 See Cadra Peterson McDaniel, Russia's Arctic Strategy: An Analysis of the Role of Diplomatic, Cooperative, and Domestic Policies, ARCTIC Inst. (Nov. 29, 2017).

${ }^{29}$ Report of the Secretary-General, Enhancing the Participation of Indigenous Peoples' Representatives and Institutions in Meetings of Relevant United Nations Bodies on Issues Affecting Them, UN Doc A/75/255 (July 27, 2020).

${ }^{30}$ See Michelle Bachelet, UN High Commissioner for Human Rights, Opening Statement for Global Update at the 42nd Session of the Human Rights Council, (Sept. 9, 2019) (suggesting Indigenous Peoples' knowledge may be crucial for addressing climate change and environmental issues). 